\title{
Pleomorphic Adenoma a Salivary Gland Tumor as Nasal Mass; Rarest Presentation
}

\author{
*Bhushan Kathuria ${ }^{1}$, Dinesh Madhur ${ }^{2}$, Himani Dhingra ${ }^{3}$ and Mohit Pareek ${ }^{4}$ \\ ${ }^{1}$ Consultant, Department of Otolaryngology, Head \& Neck Surgery, Aadhar Hosital, India \\ ${ }^{2}$ Senior resident, Department of Otolaryngology, Head \& Neck Surgery, Agroha medical college, India \\ ${ }^{3}$ Senior resident, Department of paediatric, Sion hospital Mumbai, India \\ ${ }^{4}$ Resident, Department of Otolaryngology, Head \& Neck Surgery, Post Graduate Institute of Medical Sciences, India
}

Submission: December 27, 2016; Published: January 23, 2017

*Corresponding author: Bhushan Kathuria, Consultant, Department of Otolaryngology, Head \& Neck Surgery, Aadhar Hosital, Hissar, Haryana, India, Email: kathuriabhushan56@gmail.com

\section{Abstract}

Pleomorphic adenoma of minor salivary glands can be seen at any location where minor salivary glands are present such as neck, ear, external nose and nasal cavity. However the lesions detected in nasal cavity are extremely rare. Here we describing a case of intranasal pleomorphic adenoma of the nasal septum who was previously treated as chronic sinusitis but after further investigation the correct diagnosis was made and treated accordingly.

Keywords: Nasal Mass; Pleomorphic Adenoma; Endoscopic Resection

\section{Introduction}

Salivary gland tumors represent $3 \%$ of all head and neck tumors. Among these $85-90 \%$ originates from the major salivary glands. Pleomorphic adenoma is the most common benign salivary gland tumor. Although parotid gland constitutes $60 \%$ of all pleomorphic adenomas, minor salivary glands constitute only $8 \%$ of them [1]. Pleomorphic adenoma of minor salivary glands can be seen at any location where minor salivary glands are present such as neck, ear, external nose and nasal cavity [2]. However the lesions detected in nasal cavity are extremely rare. Nasal pleomorphic adenoma is seen predominantly in females usually between the third and fifth decades of life $[3,4]$.

\section{Case Report}

A 32 years female presented to us with history of right sided nasal obstruction for the last 4 years with off and on history of nasal bleeding. There was no history of previous trauma to the nose. Before this patient was treated with oral antibiotics, oral antihistamincs, local nasal decongestant and local steroid spray by his family physician as chronic sinusitis with no improvement. Anterior Rhinoscopy revealed septum deviated to right side with a grayish, polypoidal, non-sensitive, friable mass in right nasal cavity covered with mucopurulent discharge at level of middle turbinate. Mass completely obstructing the right nasal cavity rigid endoscopy of the nose showed that the polypoidal mass seemed to originate from the nasal septum and protruding into right nasal cavity with mucopurulent discharge, touching lateral nasal wall at level of the middle turbinate and blocking right side osteomeatel complex. On left side there was a spur with enlarged middle turbinate. His weight was stable and his general health was satisfactory.

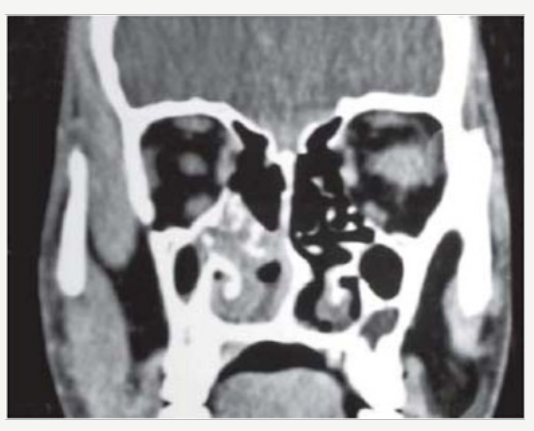

Figure 1: CECT paranasal sinuses shows mass originating from right nasal septum.

CECT paranasal sinuses (Figure 1) was done which revealed soft tissue mass in right nasal cavity originating from nasal 
septum blocking right osteomeatel complex. Bilateral ehmoids, frontal and sphenoid sinuses were clear. The lesion displaced the lateral nasal wall laterally and did not show any evidence of bony destruction. Biopsy was taken from the mass endoscopically and sent for histopathological examination. The biopsy report suggested the specimen to be fibroepithelial polyp. However considering the age of the patient, clear paranasal sinuses and nasopharynx on CECT paranasal sinuses, endoscopic removal was planned. Incision given over septum anterior to attachment of the mass, mucoperichondrial flap elevation was done with cottle's elevator under direct visualization with a 0 -degree endoscope. Mass was found not adherent to nasal septum.

A tumor mass of size approximately $2.5 \times 1.5 \times 1 \mathrm{~cm}$ was excised with small part of septal mucoperichondrium around and sent for histopathological examination. Post-operative period was uneventful and patient was discharged after 2 days of hospital stay. Histopathological report revealed features of pleomorphic adenoma revealing epithelial lined tubules, ducts, proliferation of myoepithelial cells and pseudocartilaginous areas (Figure 2). At 6 months follow up period patient is relieved of symptoms of obstruction and epistaxis, and nasal examination shows no abnormality or recurrence.

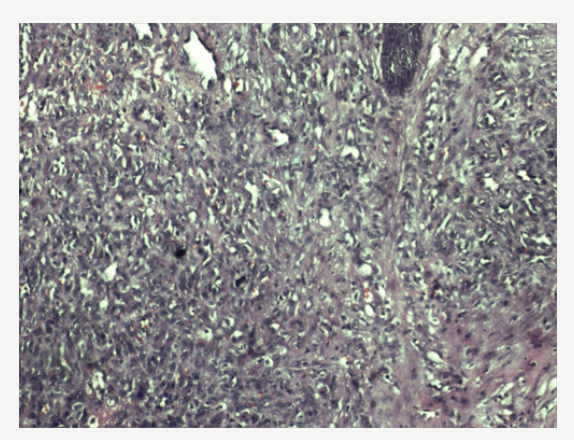

Figure 2: Histopathological report revealing epithelial lined tubules, ducts, proliferation of myoepithelial cells show spindle morphology and arranged in dense fascicles.

\section{Discussion}

The most common tumors of the major salivary glands are pleomorphic adenomas, but in rare instances, they can occur in respiratory tract (via minor salivary glands). In the upper respiratory tract, the most favoured site is the nasal cavity, followed by maxillary sinus and the nasopharynx. Cases have been reported in the nasal cavity, paranasal sinuses, nasopharynx, oropharynx, hypopharynx and the larynx [5]. The first reported case in the literature of a pleomorphic adenoma of nasal cavity was in 1929 [6]. There is no reported correlation with occupational exposure or inhaled toxic chemical compounds. Compagno and Suzuki presented their series of pleomorhic adenoma located in nasal cavity [7]. The most common site of origin was the bonycartilaginous septum. Although the vast majority of minor mucosal and serous glands are located on the lateral nasal wall, pleomorphic adenomas in the nasal cavity mostly originate from the nasal septum [8].

It is generally known to be a slow-growing tumour and, therefore, clinical symptoms appear after a long silent period. Patients commonly present with gradual worsening of unilateral nasal obstruction and occasional epistaxis. Less commonly, when the tumoural mass reaches a relatively large size, to that of the nasal cavity, external swelling of the nasal pyramid as well as pain may be present. The clinical features, such as absence of superficial ulceration, no bleeding either on touch or spontaneously and lack of invasion of surrounding structures suggest a benign nature of the mass.

Differential diagnosis of intra-nasal pleomorphic adenoma includes both malignant and benign tumours such as squamous cell carcinoma, adenocarcinoma, adenoid cystic carcinoma, mucoepidermoid carcinoma, melanoma, olfactory esthesioneuroblastoma, polyps, papillomas (including inverted papilloma), angiofibromas and osteomas [9]. Differential diagnosis can also be difficult in the presence of a neuroestesioepithelioma. Diagnosis is possible on account of the lack of an extracellular neurofibrillar structure, neurotubules, neurosecretive granules and due to the presence of mucinous material and the rarity of malpighian lobules disseminated in the pleomorphic adenoma [10].

While complete excision of the tumour with histologically clear margins is mandatory, the surgical approach will depend upon the size, location and extension. A radical and wide resection lowers the risk of recurrence, especially when the capsule is interrupted and a direct contact with the surrounding normal tissue is present. Approaches include lateral rhinotomy $[11,12]$, trans-nasal or mid-facial degloving and intra-nasal excision [13]. The present patient underwent endoscopic resection since the tumour was small enough to observe under the endoscope. The advantages of endoscopic resection include no external scar, less blood loss. Recurrences are not frequent, Compagno and Wong reported 3 cases of local recurrences in 40 patients $(7.5 \%)$, probably, as they thought, due to the amount of myxoid stroma of the tumour, which could be split into the surgical field [4].

The potential risk of malignant transformation of the pleomorphic adenoma is about $6 \%$ and is predominantly seen in the female patients [3]. The risk is increased by delay in diagnosis. There has also been a report of metastasis to the submandibular lymph-node, in a recurrent septal pleomorphic adenoma, 17 years after the first diagnosis. Even in this case, the microscopic features of both the primary and metastatic lesion were benign as a result of incomplete excision or inadvertent disruption of the tumour with consequent spread through haematogenous or lymphatic routes [14]. The outlook for intranasal pleomorphic adenomas tumors is better than for those in other ectopic sites, because they show early symptoms leading to an early diagnosis. 
Involvement of surrounding structures like bone is rare since tumors have sufficient space to expand in nasal cavity [15].

\section{Conclusion}

Early diagnosis offers the possibility of a more complete excision with adequate care being taken not to disrupt the tumour in order to prevent local and distant spread of neoplastic cells. The endoscopic approach is preferred, as it allows complete control of the margins under direct vision and reduces the post-operative recovery period when compared to open surgery. Long-term follow-up, both endoscopic and radiologic, to exclude malignancy is mandatory, even if the tumour appears to be clinically benign and resected completely.

The case highlights the importance of keeping the possibility of pleomorphic adenoma whenever a patient presents with the slow-growing unilateral mass in the nasal cavity even if it is not frequently encountered.

\section{References}

1. Prager DA, Weiss MH, Buchalter WL, Jacobs M (1991) Pleomrphic adenoma of the nasal cavity. Ann Otol Rhinol Laryngol 100(7): 600.

2. Shaheen OH (1997) Benign salivary gland tumors. In: Kerr AG (Eds.) Scott Brown's Otolaryngology. ( $6^{\text {th }}$ edn.), Butterworth Heinemann, London, UK, pp. 5/20/1-18.

3. Batsakis JG (1984) Tumors of the Head and Neck. Williams and Wilkins, Baltimore, USA, 2: 76-99.

4. Compagno J, Wong RT (1977) Intranasal mixed tumors (pleomorphic adenomas). A clinicopathologic study of 40 cases. Am J Clin Pathol 68(2): 213-218

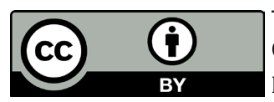

This work is licensed under Creative Commons Attribution 4.0 License

DOI: $10.19080 /$ GJO.2017.03.555613
5. Freeman SB, Kennedy KS, Parker GS, Tatum SA (1990) Metastasizing pleomorphic adenoma of the nasal septum. Arch Otolaryngol Head Neck Surg 116(11): 1331-1333.

6. Denker A, Kahler O (1929) Handush der Hals. Nasen ahrenheilkunde 5: 202.

7. Suzuki K, Moribe K, Baba S (1990) A rare case of pleomorphic adenoma of lateral wall of nasal cavity-with special refernce of statistical observation of pleomorphic adenoma of nasal cavity in Japan. J Otolaryngol Jpn 93(5): 740-745.

8. Yiotalkis I, Dinopoulou D, Ferekidis E, Manolopoulos L, Adamopoulos G (2001) Pleomorphic adenoma of the nose. Rhinology 39(1): 55-57.

9. Worthington $\mathrm{P}$ (1977) Pleomorphic adenoma of the nasal septum. Br J Oral Surgery 14(3): 245-252.

10. Couloigner V, Julien N, Molas J, Sterkers O (1993) Adenome pleomorphe de la cloison nasale. A propos d'un cas. Ann Otolaryngol Chir Cervicofac 110: 230-233.

11. Bergstrom B, Biorklund A (1981) Pleomorphic adenoma of the nasal septum- Report of two cases. J Laryngol Otol 95(2): 179-181.

12. Majed MA (1971) Pleomorphic adenoma of the nasal septum. J Laryngol Otol 85(9): 975-976.

13. Castello E, Caligo G, Pallestrini EA (1996) Su un caso di adenoma pleomorfo della fossa nasale. Acta Otorhinolaryngol Ital 16(5): 433437.

14. Wermuth MJ, Mann CH, Odere F (1988) Metastasizing pleomorphic adenoma arising in the soft palate. Otolaryngol Head Neck Surg 99(5): 505-508.

15. Golz A, Ben-Arie Y, Fradis M (1997) Pleomorphic nasoseptal adenoma. J Otolaryngol 26(6): 399-401.

\section{Your next submission with Juniper Publishers will reach you the below assets}

- Quality Editorial service

- Swift Peer Review

- Reprints availability

- E-prints Service

- Manuscript Podcast for convenient understanding

- Global attainment for your research

- Manuscript accessibility in different formats

( Pdf, E-pub, Full Text, Audio)

- Unceasing customer service

Track the below URL for one-step submission

https://juniperpublishers.com/online-submission.php 